\title{
Kryteria oceny zabezpieczenia pojazdów szynowych przed skutkami zderzeń
}

\begin{abstract}
$W$ artykule przedstawiono aktualny stan wiedzy dotyczqcy kryteriów oceny pasywnego bezpieczeństwa pojazdów szynowych przed skutkami zderzeń. Problematyka ta staje się jednym $z$ podstawowych wymagań technicznych stawianych wszystkim rodzajom pojazdów szynowych z uwagi na bezpieczeństwo personelu obstugujacego tabor szynowy, pasażerów oraz przewożonych ładunków.

Praca naukowa finansowana ze środków budżetowych na nauke w latach $2005 \div 2007$ jako projekt badawczy pt. „Teoretyczne i techniczne możliwości ksztaltowania stref zgniotu ustrojów nośnych pojazdów szynowych."
\end{abstract}

\section{Wstęp}

Odporność konstrukcji pojazdów szynowych na zderzenia jest podstawowym parametrem charakteryzującym ich ustrój nośny i dla podniesienia bezpieczeństwa w ruchu podlega ciagłemu doskonaleniu.

Podstawowe przyczyny zderzeń podczas eksploatacji można podzielić na trzy przypadki:

- prace manewrowe pojazdów, polegające na rozrządzie pojazdów i formowaniu pociagów (pojazd trakcyjny dojeżdża do wagonów z małą prędkością wynoszącą ok.7 $\mathrm{km} / \mathrm{h}$ aż do momentu zetknięcia się z nimi)

- staczanie wagonów, zwłaszcza towarowych, z górek rozrządowych $\mathrm{z}$ dopuszczalną prędkością wynoszącą $12 \mathrm{~km} / \mathrm{h}$, zgodnie $\mathrm{z}$ wymaganiami zawartymi w raporcie ERRI B12/Rp17 [17]

- niejednoczesność początku hamowania wagonów w składzie pociagu, spowodowana ograniczoną prędkością rozchodzenia się spadku ciśnienia w przewodzie głównym (tzw. fali hamowania) skutkiem czego następuje nabieganie wagonów na siebie.

Przypadki te zostały uznane jako „kontrolowane zderzenia", wymagające badań na etapie homologacji pojazdu i są określane jako tzw. próby nabiegania, natomiast ich przebieg i kryteria oceny zawarto $\mathrm{w}$ raporcie ERRI B12 Rp. 17 [17].

Z badań nad przypadkami zderzeń przeprowadzonych przez Europejski Instytut Badań Kolejowych (ERRI) wynika, że ryzyko wypadków śmiertelnych w transporcie kolejowym jest 10-cio krotnie większe aniżeli w lotniczym transporcie pasażerskim. Pomimo, że pojazdy są zbudowane zgodnie z przepisami UIC, ich pudła wykazują dwie wady, które przy wszystkich nowoprojektowanych pojazdach szynowych powinny być usunięte:

- niekontrolowany zgniot, wywołany wzrastającym przeciążeniem

- nieprzewidywalność mechanizmu zgniotu z niemożliwymi do oszacowania skutkami dla podróżnych oraz personelu obsługującego.

W nowoczesnych pojazdach szynowych odpornych na zderzenia powinno się:

- zapobiec zniszczeniu konstrukcji przez kontrolowane odkształcenie jej wybranych stref

- dokonać takiego przejęcia energii zderzenia, że zagwarantowana jest strefa przeżycia dla podróżnych i personelu

- ograniczyć tak wartości opóźnień, aby w połączeniu ze specjalnym urządzeniem wewnętrznym, zmniejszającym obciążenia działające na ciało pasażera, opóźnienia te były utrzymane $\mathrm{w}$ dopuszczalnych granicach.

2. Próby nabiegania podczas normalnej eksploatacji określonej przepisami międzynarodowymi

2.1. Próby nabiegania wagonów towarowych

\subsubsection{Warunki przeprowadzania prób}

Próby nabiegania można podzielić na dwie grupy:

- badania wstępne

- badania zasadnicze.

Badania wstępne oraz zasadnicze muszą być wykonane wg wymagań zawartych w tabeli 1 . 
Wymagania dla prób nabiegania ${ }^{(1)}$

Tabela 1

\begin{tabular}{|c|c|c|c|}
\hline \multicolumn{2}{|c|}{ Wartości graniczne } & \multirow[b]{2}{*}{ Badania wstępne } & \multirow[b]{2}{*}{ Badania zasadnicze } \\
\hline $\begin{array}{l}\text { Siła na poje- } \\
\text { dynczym }^{(2)} \\
\text { zderzaku }^{2}\end{array}$ & $\begin{array}{c}\text { Prędkość } \\
\text { Nabiegania }\end{array}$ & & \\
\hline $1500 \mathrm{kN}^{(3) \mathrm{i}(4)}$ & $12 \mathrm{~km} / \mathrm{h}$ & $\begin{array}{l}10 \text { nabiegań ze stale } \\
\text { wzrastającymi pręd- } \\
\text { kościami, z czego } 3 \\
\text { nabiegania wykonuje } \\
\text { się z prędkością } 3 \\
\mathrm{~km} / \mathrm{h}\end{array}$ & $\begin{array}{l}40 \text { nabiegań } \mathrm{z} \text { ustaloną prędkością graniczną } \\
\text { przy nabieganiach wstępnych: } \\
\text {-albo } 12 \mathrm{~km} / \mathrm{h} \text {, } \\
\text {-lub prędkość odpowiadająca sile na pojedyn- } \\
\text { czym zderzaku (3),(5),(6) }\end{array}$ \\
\hline
\end{tabular}

(1) o ile w programie badań nie podano inaczej; dla określonych wagonów, które nie moga być staczane lub nie moga być nabiegane, należy ograniczyć prędkość do $7 \mathrm{~km} / \mathrm{h}$; do takich wagonów można zaliczyć wagony kursujace w pociagach zwartych

(2) dopuszczalna tolerancja sity na pojedynczym zderzaku na końcu wagonu wynosi $\pm 200 \mathrm{kN}$, gdzie catkowita siła na zderzakach wynoszqca $3000 \mathrm{kN}$ nie powinna być przekroczona

(3) jeśli wagon próbny jest wyposażony w zderzaki kategorii C zgodnie z karta UIC 526-1 [10], wówczas wartość graniczna siły na pojedynczym zderzaku, za zgoda kolei, może być zmniejszona do $1300 \mathrm{kN}$

(4) badany wagon należy wyposażyć $w$ zderzaki o wysokim stopniu pochtaniania energii, jeśli wartość sity na pojedynczym zderzaku przy prędkości nabiegania mniejszej niż $9 \mathrm{~km} / \mathrm{h}$ wynosi już $1000 \mathrm{kN}$

(5) na życzenie kolei należy przeprowadzić nabiegania z siła większq niż $1500 \mathrm{kN}$ i prędkościq $12 \mathrm{~km} / \mathrm{h}$ na koniec badań

(6) wartość graniczna pojedynczej sity zmniejsza się do $1000 \mathrm{kN}$ dla wagonów z hydrodynamicznymi amortyzatorami o dużym skoku zgodnie z karta UIC 529 [11]

Próby nabiegania przeprowadza się dla wagonów towarowych w stanie próżnym, aby sprawdzić połączenie pomiędzy nadwoziem wagonu i wózkami oraz zachowanie się nadwozia wagonu. Próby nabiegania w stanie próżnym przeprowadza się $\mathrm{w}$ przy wzrastających prędkościach od 8 do $12 \mathrm{~km} / \mathrm{h}$ tak, aby zarejestrować krzywą przyspieszeń w funkcji prędkości zgodnie z załącznikiem K raportu ERRI B12Rp 17 [17].

Próby nabiegania przeprowadza się dla wagonów towarowych w stanie ładownym, aby sprawdzić oddziaływanie ładunku na pudło, a w szczególności na ściany czołowe. W przypadku klasycznych wagonów platform przeprowadzenie prób $\mathrm{w}$ stanie ładownym nie jest konieczne. Próby nabiegania przeprowadza się na prostym odcinku toru, przy czym na badany, nieruchomy wagon $\mathrm{w}$ stanie niezahamowanym nabiega wagon taran ( lub odwrotnie). Wagon taran został zdefiniowany $w$ raporcie ERRI B12 Rp.17 [17] jako otwarty czteroosiowy wagon-węglarka (oznaczenie kolejowe Eas lub Eaos) o konstrukcji standardowej według karty UIC 571-2 [13], załadowany do masy brutto 80t. Ze względu na ochronę ładunku konieczna jest znajomość przyspieszenia działającego na pojazd i dlatego mierzy się je w środku powierzchni ładunkowej badanego wagonu w stanie próżnym oraz ładownym.

Badany wagon jako ładowny należy załadować, w zależności od jego typu, następująco:
- wagony kryte, wagony otwarte, wagony chłodnie ( wagony izotermiczne, wagony zasobnikowe posiadające zmagazynowane medium chłodzące, wagony $z$ agregatem chłodniczym, wagony $z$ agregatem grzewczym):

ładunek w postaci worków ze żwirem lub innym rodzajem ładunku, który nadaje się do całkowitego wypełnienia pojemności użytkowej wagonu; w przypadku wagonów chłodni z ładunkiem wiszącym próby należy przeprowadzać według odrębnych wymagań określonych w programie badawczym

- wagony otwarte:

standardowa drobnica według przepisów UIC lub inny ładunek, przy którym przy maksymalnym obciążeniu otrzymuje się taką samą wysokość środka ciężkości ( dla tego rodzaju badań zaleca się po każdej próbie nabiegania wykonanie uderzenia z przeciwnej strony, aby ladunek zajął pozycję wyjściowa)

- wagony specjalne przeznaczone do transportu określonych produktów ( wagony samowyładowcze oraz wagony przeznaczone do transportu blach w kręgach):

ładunek muszą stanowić produkty, które są przeważnie transportowane przez te wagony ( konsystencja, środek ciężkości itd.)

\section{- wagony cysterny:}


w miarę możliwości ładunek muszą stanowić produkty, które sa przewożone lub ewentualnie woda, przy czym należy spełnić warunek wymagany przez przepisy RID- Reglement concernant le transport International ferroviaire des marchendises Dangereuses tzn. przestrzeń niewypełniona + ładunek; jeśli gęstość przewożonego ładunku mocno odbiega od gęstości wody, wówczas należy uwzględnić następujące zalecenia:

- jeśli gęstość przewożonego ładunku jest dużo większa od jedności, to utrzymanie maksymalnego stopnia napełnienia za pomocą wody prowadzi do mniejszej masy brutto $\mathrm{m}$, aniżeli rzeczywista $\mathrm{M}$; w takim przypadku konieczna prędkość nabiegania wagonu tarana musi być powiększona przez współczynnik K, który wyraża się wzorem:

$$
K=\sqrt{\frac{M \cdot(80 t+m)}{m \cdot(80 t+m)}}
$$

- jeśli gęstość produktu jest znacznie mniejsza od gęstości wody, to maksymalny ładunek nie umożliwia utrzymania maksymalnego stanu napełnienia wagonu; w takim przypadku nie należy uwzględniać podczas pomiarów oddziaływań sił wtórnych, które wynikają z ruchu cieczy i jej reakcji na ścianki zbiornika.

Różnica wysokości zderzaków pomiędzy wagonem badanym oraz wagonem-taranem może wynosić maksymalnie $50 \mathrm{~mm}$ dla prób nabiegania $\mathrm{w}$ stanie próżnym oraz w stanie ładownym.

\subsubsection{Kryteria prób nabiegania wagonów towaro- wych}

Kryteria dotyczące prób nabiegania sprowadzają się do spełnienia następujących warunków wymienionych w raporcie ERRI B12/ Rp.17 [17]:

- różne próby nabiegania nie mogą spowodować $\mathrm{w}$ badanym wagonie żadnych widocznych odkształceń trwałych ( naprężenia rejestruje się we wszystkich krytycznych miejscach połączeń wózek-ostoja, ostoja-pudło wagonu)

- skumulowane względne odkształcenia trwałe w wyniku nabiegań wstępnych oraz z nabiegań zasadniczych muszą wynosić poniżej $2 \%$ i muszą się ustabilizować przed wykonaniem 30-tej próby z serii nabiegań zasadniczych ( nie dotyczy to części wagonowych, które podlegają odrębnym specyficznym przepisom)

- zmiany wymiarów zasadniczych nie mogą zmniejszać bezpieczeństwa eksploatacyjnego wagonu.

\subsection{Próby nabiegania wagonów osobowych 2.2.1. Warunki przeprowadzania prób}

W przypadku wagonów osobowych próby nabiegania przeprowadza się zgodnie z wymaganiami przedstawionymi w karcie UIC 566 [12]. Na wagon osobowy kompletnie wyposażony, przygotowany do eksploatacji oraz w stanie próżnym (niezajętym przez pasażerów) i swobodnie stojący nabiega na prostym torze wagon-taran o masie całkowitej wynoszącej $80 \mathrm{t}$. Wymagania dotyczace wagonu tarana zawiera raport ERRI B12 Rp.17 [17]. Wagon osobowy powinien być wyposażony w zderzaki lub element amortyzujący sprzęgu samoczynnego. Wyposażenie wagonu prototypowego musi odpowiadać wagonowi, który będzie produkowany $\mathrm{w}$ ramach produkcji seryjnej. Próby przeprowadza się ze wzrastającymi stopniowo prędkościami ( 4,6 oraz $8 \mathrm{~km} / \mathrm{h}$ ), aż do osiagnnięcia prędkości $10 \mathrm{~km} / \mathrm{h}$ albo też mierzonej siły zderzakowej 1000 $\mathrm{kN}$ lub maksymalnego przyspieszenia $5 \mathrm{~g}$. W celu przeprowadzenia próby należy zastosować zderzaki bądź elementy sprężyste sprzęgu samoczynnego o znanych charakterystykach.

Podczas prób nabiegania muszą być równocześnie mierzone następujące wartości:

- wartości naprężeń i przyspieszeń w krytycznych punktach konstrukcji ( $\mathrm{w}$ połączeniach wagonu pasażerskiego z wózkami i zamocowaniach części przytwierdzonych do wagonu, a w szczególności części o dużej masie)

- odkształcenia względne rejestrowane przy pomocy tensometrów

- przyspieszenia we wszystkich kierunkach (wzdłużnym, poprzecznym i pionowym)

- siły działające na zderzaki lub elementy sprężyste sprzęgu samoczynnego

- rzeczywiste prędkości nabiegania.

\subsubsection{Kryteria dla prób nabiegania wagonów oso- bowych}

Kryteria oceny prób nabiegania sprowadzają się do spełnienia następujących warunków:

- w żadnym punkcie konstrukcji nie może wystąpić odkształcenie trwałe

- po próbie nabiegania wagon musi być zdolny do pełnienia swojej funkcji

- żaden element wagonu nie może być uszkodzony.

\section{Odporność konstrukcji pojazdów szynowych na skutki zderzeń}

\subsection{Pojeccia ogólne}

Poważnym problemem technicznym, jaki pojawił się w eksploatacji pojazdów szynowych, jest odporność konstrukcji na działanie sił wynikających ze zderzeń pojazdów szynowych podczas wypadków, traktowanych jako zjawiska nadzwyczajne. Zderzenia takie 
odbywają się przy większych prędkościach, niż wymienione w tzw. zwykłej, rutynowej, kontrolowanej eksploatacji. Traktując takie zderzenia jako zjawiska nadzwyczajne wprowadzono pojęcie bezpieczeństwa pasywnego oraz aktywnego pojazdów szynowych. Obydwa te pojęcia zostały zdefiniowane w projekcie prEN 15227 [14].

Bezpieczeństwo pasywne (ang. „passive safety”, niem. „passive Sicherheit”) dotyczy zmniejszenia skutków wypadków oraz polepszenia ochrony pasażerów przed skutkami zderzeń.

Bezpieczeństwo aktywne (ang. ,active safety” , niem. ,aktive Sicherheit”) zmniejsza prawdopodobieństwo wystapienia wypadku oraz ostrości jego skutków.

W ostatnich latach bezpieczeństwo pasywne jako część składowa bezpieczeństwa systemowego osiągnęła istotny postęp.

Przyczyniły się do tego projekty badawcze finansowane przez Unię Europejską:

- SAFETRAIN: „Bezpieczeństwo europejskiego taboru kolejowego. Projektowanie pojazdu i ochrona pasażerów." $[5,18]$

- TRAINSAFE: „Pasywne bezpieczeństwo w kolejnictwie" [6]

- SAFETRAM: „Pasywne bezpieczeństwo tramwajów w Europie" [4].

Program badawczy SAFETRAIN był realizowany dla zespołów trakcyjnych, natomiast program SAFETRAM zrealizowano dla lekkich pojazdów ruchu lokalnego tzn. lekkich pojazdów trakcyjnych, pojazdów kolei miejskiej, wagonów metra i pojazdów tramwajowych (ang. Light Rail Vehicle-LRV).

Uzyskane informacje $\mathrm{i}$ wynikające $\mathrm{z}$ nich wymagania dotyczące bezpieczeństwa przed wypadkami, określane również jako „kontrolowane zachowanie się konstrukcji pojazdu i jego podzespołów w przypadku kolizji lub wypadku" zostaną wprowadzone do przepisów europejskich i należy je uwzględnić w przyszłych konstrukcjach pojazdów szynowych. Dotyczy to zespołów trakcyjnych przystosowanych do wysokich prędkości, lokomotyw, wagonów osobowych i towarowych.

\subsection{Kategorie pojazdów szynowych oraz wielkość przenoszonej sily wzdłużnej}

Współczesne pojazdy szynowe są budowane zgodnie z obecnie obowiązującymi przepisami, które przewidują jako istotne kryterium wyłącznie przeniesienie minimalnej siły wzdłużnej bez wystapienia odkształcenia trwałego.

Wielkość tej siły, przyłożonej do zderzaków, jest uzależniona od rodzaju pojazdu oraz regionu świata i wynosi:

-pojazdy tramwajowe: 250 do $600 \mathrm{kN}$

-pojazdy metra: 500 do $1000 \mathrm{kN}$

-pojazdy trakcyjne w Europie: $1500 \mathrm{kN}$ -pojazdy trakcyjne w Japonii: $1000 \mathrm{kN}$

-pojazdy trakcyjne w Ameryce Północnej: 3600

$\mathrm{kN}$.

Projekt normy prEN 15 227: 2005 [14] wprowadza podział pojazdów szynowych na kategorie, przyjmując jako kryterium wielkość przenoszonej siły wzdłużnej. Wartości sił wzdłużnych przedstawiono w tabeli 2.

\section{Wielkości sil wzdłużnych dla różnych kategorii} pojazdów szynowych

Tabela 2

\begin{tabular}{|c|c|l|}
\hline $\begin{array}{c}\text { Kategoria } \\
\text { pojazdu } \\
\text { szynowego }\end{array}$ & $\begin{array}{c}\text { Siła } \\
\text { wzdłużna } \\
\text { zderzenia }\end{array}$ & \multicolumn{1}{|c|}{$\begin{array}{c}\text { Rodzaj pojazdu } \\
\text { szynowego }\end{array}$} \\
\hline P-I & $2000 \mathrm{kN}$ & $\begin{array}{l}\text { lokomotywy i wago- } \\
\text { ny osobowe }\end{array}$ \\
\hline P-II & $1500 \mathrm{kN}$ & zespoły trakcyjne \\
\hline P-III & $800 \mathrm{kN}$ & pojazdy metra \\
\hline P-IV & $400 \mathrm{kN}$ & $\begin{array}{l}\text { pojazdy metra o ma- } \\
\text { łej nośności i pojazdy } \\
\text { tramwajowe o dużej } \\
\text { nośności }\end{array}$ \\
\hline P-V & $200 \mathrm{kN}$ & pojazdy tramwajowe \\
\hline
\end{tabular}

Spełnienie kryterium siły wzdłużnej w przypadku niektórych pojazdów jest niezwykle trudne i zostało zrealizowane dla pojazdów metra dopiero w przypadku zespołów trakcyjnych typu SG2 produkcji firmy Bombardier Transportation dla miejskiego przedsiębiorstwa Rotterdamu, które są dostosowane do przeniesienia siły wzdłużnej wynoszącej $800 \mathrm{kN}$ ( po-

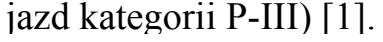

\subsection{Energia kinetyczna poruszającego się pojazdu}

Jeśli weźmie się pod uwagę, że energia kinetyczna pojazdu o masie $50000 \mathrm{~kg}$ przy prędkości $15 \mathrm{~km} / \mathrm{h}$ wynosi około $450 \mathrm{~kJ}$, natomiast przy prędkości 40 $\mathrm{km} / \mathrm{h}$ nawet $3 \mathrm{MJ}$ oraz że możliwość przejmowania energii przez cztery zderzaki o wysokiej wydajności wynosi $280 \mathrm{~kJ}$, to taki pojazd może przejąć w sprężystym zakresie odkształceń materiałowych tylko $25 \mathrm{~kJ}$ przy jednostronnym nabieganiu i przy symetrycznym ściskaniu $50 \mathrm{~kJ}$, co pozwala uniknąć uszkodzeń pojazdów w trakcie prac manewrowych. W tabeli 3 przedstawiono wartości energii kinetycznej $E_{k}$ dla różnych pojazdów szynowych o masie $m$ i prędkości $v$ korzystając $\mathrm{z}$ uproszczonego wzoru:

$$
E_{K}=\frac{1}{2} \cdot m \cdot v^{2}
$$

Uproszczenie polega na pominięciu udziału energii kinetycznej mas wirujących, wyrażonej ich momentem bezwładności $J$ oraz prędkością kątową $\omega$. Uwzględniając tę część energii wzór (2) przyjmuje postać: 
Zestawienie wartości energii kinetycznych dla różnych pojazdów szynowych

Tabela 3

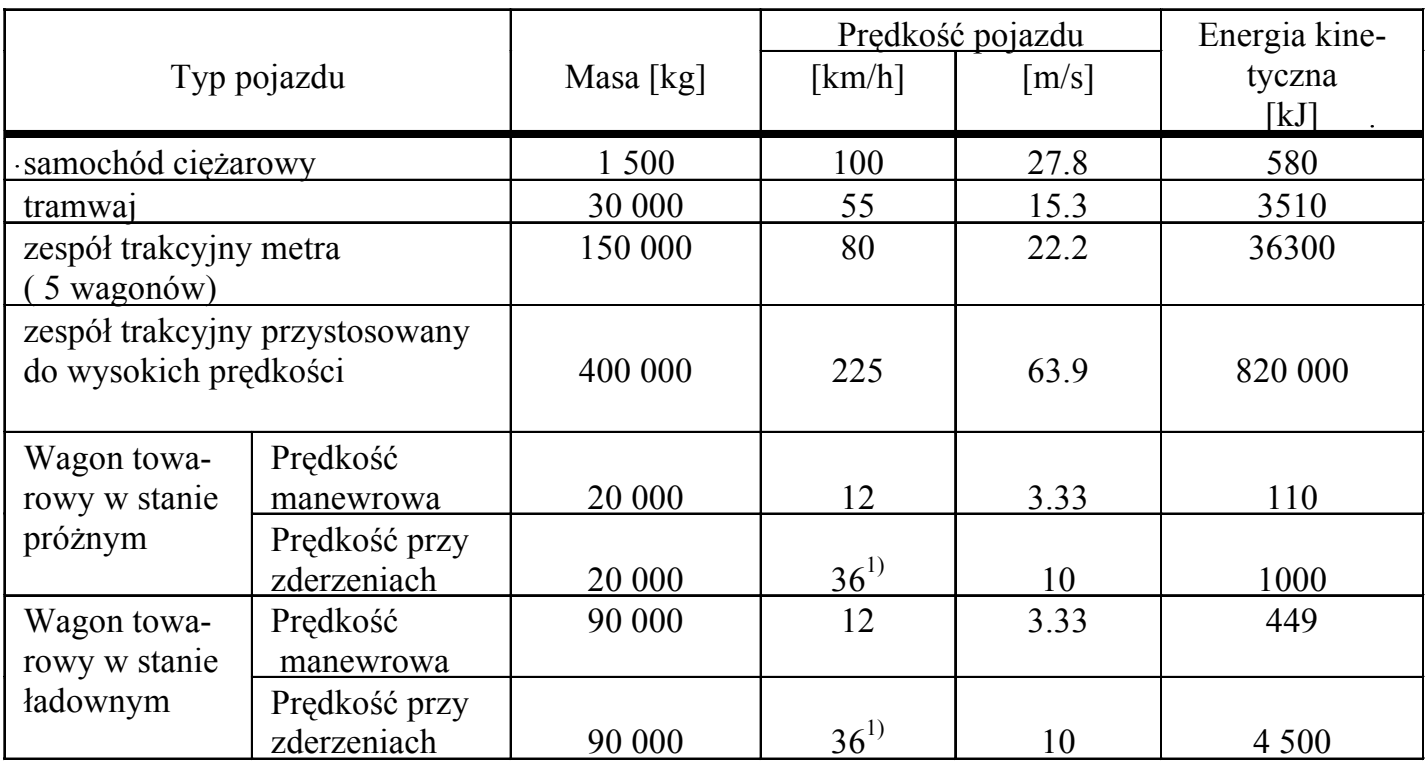

1) prędkość zderzenia na podstawie prEN 15227:2005 [14]

$$
E_{K}=\frac{1}{2} \cdot m \cdot v^{2}+\frac{1}{2} \cdot J \cdot \omega^{2}
$$

gdzie:

m-masa nadwozia pojazdu w $\mathrm{kg}$,

v-prędkość liniowa pojazdu w m/s,

J- masowy moment bezwładności w $\mathrm{kgm}^{2}$,

$\omega$ - prędkość kątowa w rad/sek.

Jak można wywnioskować $\mathrm{z}$ doświadczeń eksploatacyjnych, kolizje pojazdów szynowych $\mathrm{z}$ wysokimi prędkościami przetokowymi występują bardzo rzadko. Stan dzisiejszy można podsumować następująco:

- jednolite przepisy $\mathrm{w}$ tym zakresie nie istnieją, natomiast norma europejska EN 15227 [14] jest projektem i znajduje się $\mathrm{w}$ fazie opiniowania przez poszczególne zarządy europejskie

- niektóre zarządy kolejowe oraz urzędy nadzoru kolejowego opracowały przepisy wytrzymałościowe lub zdefiniowały wartości dotyczące przejmowania energii

- dla ruchu z wysokimi prędkościami przygotowano warunki techniczne współpracy (TSI) zakładające trzy warianty możliwych zderzeń: zderzenie z prędkością względną $36 \mathrm{~km} / \mathrm{h}$ dwóch pociagów ( wariant I), zderzenie czołowe zespołu trakcyjnego poruszającego się $\mathrm{z}$ prędkością $36 \mathrm{~km} / \mathrm{h}$ z wagonem towarowym o masie 80t jako wagonem taranem ( wariant II), kolizja z przeszkodą o masie $15 \mathrm{t}$ ( samochód ciężarowy) i prędkością $108 \mathrm{~km} / \mathrm{h}$ ( wariant III),

- dla ruchu tramwajowego opracowano w ramach programu SAFETRAM cztery warianty zderzeń, które przedstawiono $\mathrm{w}$ tabeli 4.
Zestawienie wariantów zderzeń opracowanych dla ruchu tramwajowego [3]

Tabela 4

\begin{tabular}{|c|c|c|c|c|}
\hline $\begin{array}{l}\text { Ozna- } \\
\text { czenie } \\
\text { wa- } \\
\text { riantu }\end{array}$ & $\begin{array}{l}\text { Opis warian- } \\
\text { tu zderzenia }\end{array}$ & $\begin{array}{l}\text { Pręd- } \\
\text { kość w } \\
{[\mathrm{km} / \mathrm{h}]}\end{array}$ & $\begin{array}{c}\text { Ener- } \\
\text { gia w } \\
{[\mathrm{kJ}]}\end{array}$ & Uwagi \\
\hline C1 & $\begin{array}{c}\text { Hamowanie } \\
\text { awaryjne }\end{array}$ & & & $\begin{array}{l}\text { Opóźnienie } \\
\text { hamowania } \\
2.73 \mathrm{~m} / \mathrm{s}^{2}\end{array}$ \\
\hline $\mathrm{C2}$ & $\begin{array}{c}\text { Kolizja } \\
\text { czołowa z } \\
\text { tramwajem o } \\
\text { identycznej } \\
\text { konstrukcji }\end{array}$ & 20 & 270 & $\begin{array}{l}\text { Każdy z po- } \\
\text { jazdów tram- } \\
\text { wajowych ab- } \\
\text { sorbuje } 50 \% \\
\text { energii zde- } \\
\text { rzenia }\end{array}$ \\
\hline $\mathrm{C3}$ & $\begin{array}{c}\text { Kolizja } \\
\text { boczna z } \\
\text { prawej stro- } \\
\text { ny pod ką- } \\
\text { tem } 45^{\circ} \mathrm{z} \\
\text { samochodem } \\
\text { dostawczym } \\
\text { o masie } 3 \mathrm{t}\end{array}$ & 25 & 66 & $\begin{array}{l}\text { Wagon do- } \\
\text { stawczy jest } \\
\text { zamodelowany } \\
\text { przez sztywną } \\
\text { ścianę o masie } \\
\text { 3t }\end{array}$ \\
\hline C4 & $\begin{array}{l}\text { Kolizja czo- } \\
\text { łowa z po- } \\
\text { jazdem re- } \\
\text { gionalnej ko- } \\
\text { lei miejskiej } \\
\text { o masie } 55 \text { t }\end{array}$ & 10 & 83 & $\begin{array}{l}\text { Pojazd regio- } \\
\text { nalny jest za- } \\
\text { modelowany } \\
\text { przez sztywną } \\
\text { ścianę o masie } \\
55 \mathrm{t}\end{array}$ \\
\hline
\end{tabular}

\subsection{Rozwój technicznej koncepcji bezpieczeństwa przed zderzeniami wg kolei niemieckich DB AG [3]}

Rozwój technicznej koncepcji bezpieczeństwa przed zderzeniami wg kolei DB AG przedstawiono na schemacie blokowym (rys.1). 


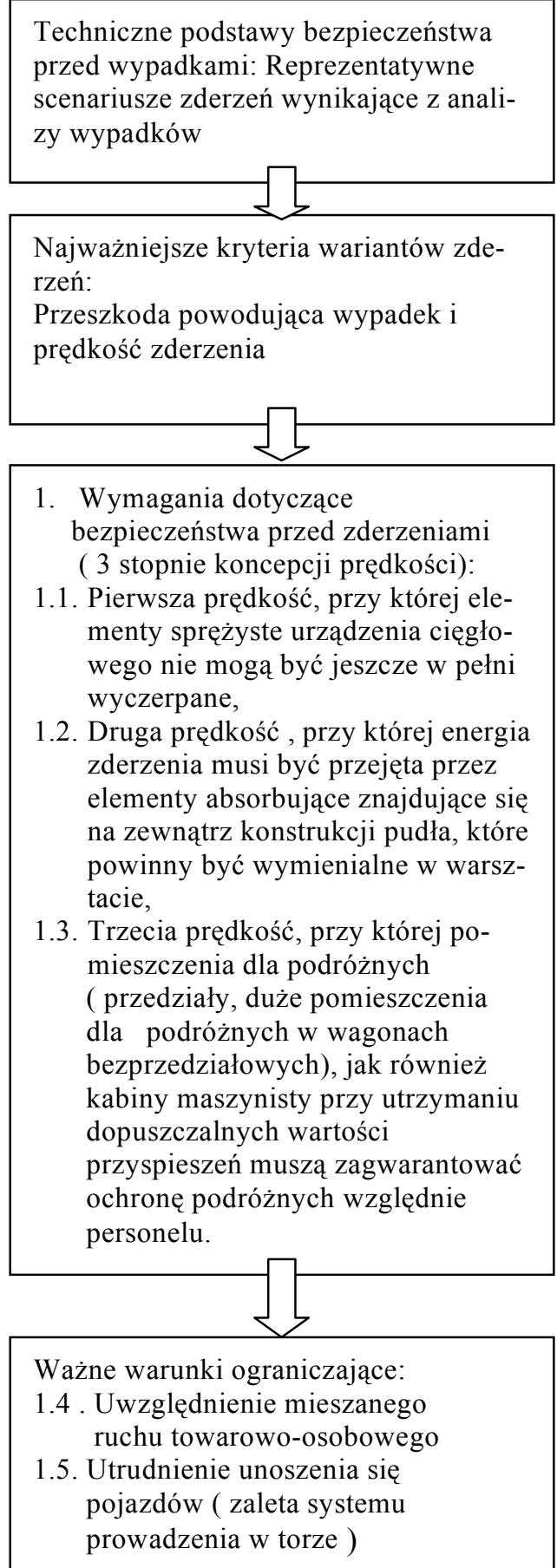

Rys.1 Schemat blokowy rozwoju technicznej koncepcji bezpieczeństwa pojazdów szynowych wg DB AG 「3]

Przy tworzeniu projektów przepisów i wytycznych do projektowania pojazdów szynowych jako kryterium oceny jakości wytrzymałości na zderzenia współczesnych pudeł pojazdów przyjęto:

- $\quad$ zabezpieczenie przed zniszczeniem konstrukcji i zapewnienie kontrolowanego odkształcenia wybranych przestrzeni w ten sposób, że energia kinetyczna zderzenia będzie tak pochłonięta, aby zagwarantować pomieszczenie „,bezpieczeństwa" dla podróżnych oraz personelu
- $\quad$ wartości opóźnienia ( przyspieszenia) będą tak ograniczone, że wynikające $\mathrm{z}$ nich siły będą przyjmowały wartości graniczne, które można zaakceptować z punktu widzenia oddziaływania na organizm ludzki.

Tworząc kryteria konstrukcyjne zabezpieczenia pojazdów przed skutkami zderzeń należy wziąć pod uwagę, że bardzo ważnymi aspektami tego zagadnienia są tzw. eksploatacyjne kryteria bezpieczeństwa pojazdów szynowych, które można przedstawić w następujący sposób:

- $\quad$ nie mogą w żadnej chwili prowadzić do zmniejszenia bezpieczeństwa podróżnych znajdujących się w konwencjonalnym pojeździe

- $\quad$ nie mogą prowadzić do zwiększonych kosztów wytwarzania pojazdów szynowych

- $\quad$ innowacyjne konstrukcje pojazdów szynowych nie mogą stanowić przeszkody do obniżenia kosztów dostawczych oraz eksploatacyjnych.

Biorąc pod uwage kryterium przejmowania energii, cały pojazd można podzielić na pięć stref (rys.2). Strefy te posiadają oryginalne nazwy w języku angielskim wg prEN 15227:2005[14], a mianowicie:

-strefa A:coupler-recoverable (normal buffing) zone- strefa normalnych zderzeń urządzenie cięgłowo -zderzne+ zderzaki posiadające liniową charakterystykę siłaprzemieszczenie-normalna eksploatacja

-strefa B: coupler-sacrificial zone- strefa odkształceń trwałych urządzenie cięgłowozderzne + zderzaki+elementy rozpraszające energię ( niem. „crashelemente”) rozpraszanie energii przy zderzeniach nadzwyczajnych

-strefa C: anti-climber zone-strefa zabezpieczająca przed unoszeniem się pojazdu podczas zderzenia

-strefa D: structure collapse zone - strefa zgniotu konstrukcji konstrukcja rozpraszająca energię

-strefa E: passenger/crew survival cell zone- strefa gwarantująca przeżycie dla podróżnych i personelu obsługującego pociąg, która nie powinna podlegać żadnym deformacjom.

Strefa zgniotu ( collapse zone) jest definiowana jako część pojazdu szynowego, przeważnie strefa końcowa pojazdu szynowego, która jest zaprojektowana do zgniotu w kontrolowany sposób, jeśli obciążenia przekraczają poziom maksymalny pojawiający się $\mathrm{w}$ eksploatacji. 
Strefa gwarantująca przeżycie ( pasenger /crew survival cell zone) jest definiowana jako objętość nadwozia pojazdu zawierająca przestrzeń, która powinna być zachowana w czasie dopuszczalnego zderzenia ( np. powierzchnie zajęte przez pasażerów, nie wliczając dostępu przedsionków wagonu, korytarzy).

Zgniot (crushing) przekroczenie deformacji plastycznej, która znacznie zmniejsza przestrzeń zajmowaną przez konstrukcję.

Strefa A obejmuje urządzenie pociągowo-zderzne z jego elementami sprężystymi. Z reguły te elementy posiadają liniową charakterystykę, natomiast deformacje mają charakter sprężysty. W strefie B pracuje element pochłaniający energię, posiadający cechy zamienności oraz możliwość regulacji. W tym przypadku chodzi o plastycznie odkształcalne elementy, jak np. metalowe rury i bloki w formie konstrukcji węzowej lub urządzenie pociagowo-zderzne. Obydwie strefy A i B maja za zadanie przejąc ostre zderzenia bez uszkodzenia konstrukcji pojazdu. Strefa $\mathbf{C}$ występuje dla pojazdów, które są wyposażone w zabezpieczenie przed unoszeniem. Zabezpieczenie to stanowią lekkie, wymienialne elementy, rozpraszające energię zderzenia, które są rozmieszczone równolegle do stopnia $\mathbf{B}$ i łączą ochronę przed unoszeniem z czołownicą konstrukcji. Strefa D jest najważniejsza, najbardziej efektywną strefą zgniotu, gdzie przez w pełni kontrolowaną deformację mogą być przejęte duże ilości energii. W przypadku zespołu trakcyjnego TGV energia przejęta przez tą strefę wynosi nawet $30 \mathrm{~kJ}$ na kg masy pojazdu. Strefa $\mathbf{E}$ jest zakwalifikowana jako strefa gwarantująca przeżycie dla pasażerów i personelu i nie powinna być zdeformowana. W przypadku zwykłych aluminiowych konstrukcji integralnych wykonanych ze wzdłużnych, dwuściennych profili na całym obwodzie pudła wagonu opór przeciw deformacjom tych stref wynosi 6 i $10 \mathrm{MN}$ i nie ma żadnego ryzyka powstania lokalnych niestabilności.

Wykres przedstawiony na rys.2a stanowi wyidealizowany teoretyczny przebieg sił w funkcji przemieszczeń (ang. idealised behaviour), natomiast na rys.2b przedstawiono typowy, rzeczywisty przebieg ( ang. typical real bahaviour).

a) teoretyczny przebieg próby

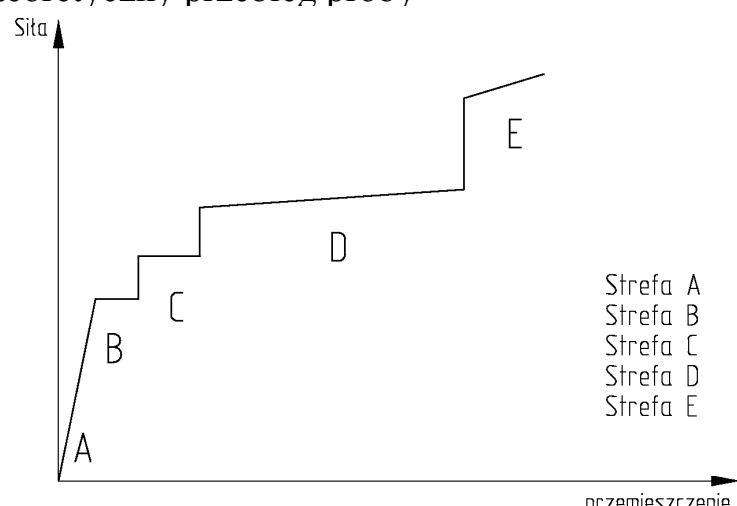

b) rzeczywisty przebieg próby

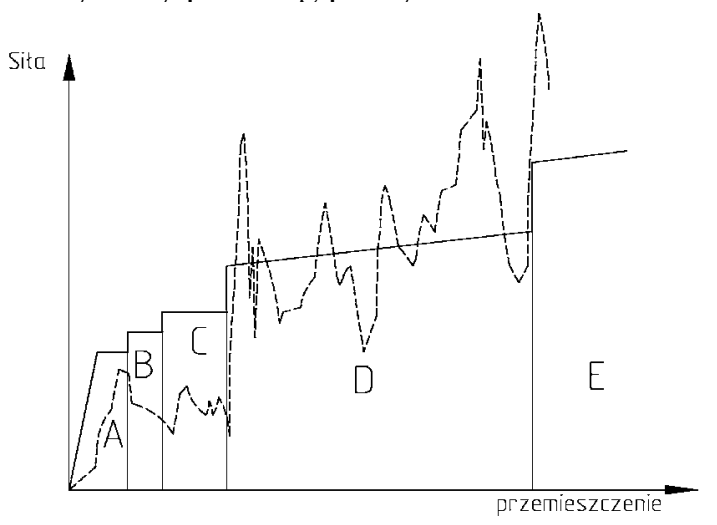

Rys.2. Przebieg sił w funkcji przemieszczeń dla poszczególnych stref pojazdu podczas zderzeń pojazdów

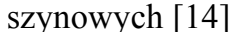

\subsection{Rozwój technicznej koncepcji bezpieczeństwa przed zderzeniami wg prEN 15227:2005 [14]}

Projekt normy prEN 15227:2005 [14] zawiera podstawowe definicje pojęć związanych ze zderzeniami pojazdów szynowych, klasyfikację (podział) pojazdów szynowych na kategorie z uwagi na wprowadzone kryterium przenoszonej, maksymalnej siły wzdłużnej oraz warianty zderzeń.

Projekt prEN 15227:2005 [14] przewiduje zderzenia oceniane wg 6-ciu kryteriów ( w nawiasie nazwy angielskie):

- opór przed unoszeniem się pojazdu ( resisting overriding)

- pochłonięta energia zderzenia ( absorbing collision energy)

- zachowana strefa przeżycia ( preserving survival space)

- kryterium zmiany opóźnienia ( limiting the deceleration rate)

- wgłębienie w strefę przeżycia (resisting intrusion into the survival space)

- minimalizacja konsekwencji zderzenia ( minimizing the consequences of hitting a track obstruction).

Projekt normy prEN 15227:2005 [14] przewiduje również cztery referencyjne, najbardziej reprezentatywne warianty zderzeń (ang. reference collision scenerio):

- wariant I: zderzenie czołowe dwóch identycznych zespołów trakcyjnych

- wariant II: zderzenie czołowe z klasycznym pojazdem szynowym, wyposażonym w zderzaki

- wariant III: zderzenie czołowe zespołu trakcyjnego z ciężką przeszkodą ( np. samochód ciężarowy na skrzyżowaniu)

- wariant IV: zderzenie zespołu trakcyjnego ( kategorii I do IV ) z lekką przeszkodą ( np. samochód na skrzyżowaniu, zwierzęta). 
Ww. warianty zderzeń przedstawiają reprezentatywne „scenariusze" zderzeń i zostały opracowane na bazie analizy wypadków kolejowych, w których doszło do zderzeń opisanych w raporcie ERRI B 205 Rp1 [15]. W przypadku pojazdów osobowych prEN 15227:2005 [14] definiuje masę zderzenia (ang. collisions mass) jako sumę masy pojazdu w stanie próżnym+ masa pasażerów, zajmujących 50\% miejsc siedzących.

Wymagania dotyczące symulacji ww. wariantów zde-

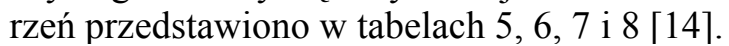

Zestawienie wymagań dla I-szego wariantu zderzeń wg prEN 15227:2005 [14]

Tabela 5

\begin{tabular}{|c|c|c|c|c|}
\hline \multicolumn{5}{|c|}{ Prędkość zderzenia pojazdów pasażerskich $\mathrm{v}_{\mathrm{c}}{ }^{\mathrm{a}}$} \\
\hline P-I & P-II & P-III & P-IV & P-V \\
\hline \multicolumn{5}{|c|}{ Sumaryczne opóźnienie hamowania $1.0 \mathrm{~m} / \mathrm{s}^{2 \mathrm{~b}, \mathrm{c}}$} \\
\hline $36 \mathrm{~km} / \mathrm{h}$ & $36 \mathrm{~km} / \mathrm{h}$ & $36 \mathrm{~km} / \mathrm{h} \mathrm{d}$ & $36 \mathrm{~km} / \mathrm{h} \quad \mathrm{d}$ & $15 \mathrm{~km} / \mathrm{h}$ \\
\hline
\end{tabular}

a. warunki zderzenia: zespoly trakcyjne niehamowane na torze prostym

b. jeśli systemy aktywnego bezpieczeństwa gwarantuja, że ryzyko zderzenia jest większe niż w normalnej europejskiej eksploatacji, wówczas należy ustalić większa prędkość zderzenia $v_{c}$

c. sumaryczne opóźnienie hamowania $1.0 \mathrm{~m} / \mathrm{s}^{2}$. Prędkość zderzenia może być zmniejszona, jeśli pojazdy posiadaja możliwość hamowania bezpieczeństwa odbywajacego się z opóźnieniem $>1.0 \mathrm{~m} / \mathrm{s}^{2}$. Zmniejszona prędkość może być określana na podstawie nastęujacej formuty:

$V_{\text {red }}=v_{c}\left(1-\left(11 a_{d}-1.0\right) / 36 \geq 25 \mathrm{~km} / \mathrm{h}\right.$

d. normalna prędkość zderzenia dla pojazdów kategorii $P-I I I i$ P-IV może być zmniejszona do $25 \mathrm{~km} / \mathrm{h}$, jeśli wystęuje automatyczny system zabezpieczenia jazdy pociagów i sieć jest izolowana od innych typów pojazdów tocznych $i$ obstuga eksploatacji na wszystkich liniach odbywa się $w$ jednym kierunku.

\section{Zestawienie wymagań dla II-giego wariantu zderzeń}

Tabela 6

\begin{tabular}{|c|c|c|c|c|}
\hline \multicolumn{4}{|c|}{ Prędkość zderzenia pojazdów pasażerskich } & $\mathbf{v}_{\mathbf{c}}{ }^{\mathbf{a}, \mathbf{b}, \mathbf{c}, \mathbf{d}}$ \\
\hline P-I & P-II & P-III & P-IV & P-V \\
\hline $36 \mathrm{~km} / \mathrm{h}^{\mathrm{e}}$ & $36 \mathrm{~km} / \mathrm{h}^{\mathrm{e}}$ & $36 \mathrm{~km} / \mathrm{h}^{\mathrm{e}}$ & $\begin{array}{l}36 \mathrm{~km} / \mathrm{h}^{\mathrm{e}} \\
10 \mathrm{~km} / \mathrm{h}^{\mathrm{g}}\end{array}$ & $10 \mathrm{~km} / \mathrm{h}^{\mathrm{f}}$ \\
\hline
\end{tabular}

a. warunki zderzenia: zespoty trakcyjnel pojazdy szynowe niehamowane na torze prostym

b. jeśli systemy aktywnego bezpieczeństwa gwarantuja, że ryzyko zderzenia jest większe niz $w$ normalnej europejskiej eksploatacji, wówczas należy ustalić większq prędkość zderzenia $v_{c .}$ Prędkość zderzenia powinna bazować na lokalnej statystyce wypadków lub $w$ oparciu o inne oceny ryzyka.

c. sumaryczne opóźnienie hamowania $1.0 \mathrm{~m} / \mathrm{s}^{2}$. Prędkość zderzenia może być zmniejszona, jeśli pojazdy kategorii PI,P-II,P-III i P-IV posiadaja możliwość hamowania bezpieczeństwa, $z$ opóźnieniem $>1.0 \mathrm{~m} / \mathrm{s}^{2}$. Zmniejszona prędkość może być określana na podstawie nastęujacej formuly: $V_{\text {red }}=v_{c}\left(1-\left(11 a_{d}-1.0\right) / 36\right) \geq 25 \mathrm{~km} / \mathrm{h}$

d. warunek pochtoniętej energii przez zderzaki (karta UIC 5261 [107) lub sprzęi automatyczne powinien być uwzględniony e. dla pojazdów kategorii P-I i P-II wagon, który należy uwzględnić powinien być zgodny $z$ wyspecyfikowanym $w$ karcie UIC 571-2 [13] o masie 80 t, wyposażonym w zderzaki kategorii A. Dla pozostałych kategorii pojazdów, dla których sq określone warunki zderzeń, wagon powinien być reprezentowany przez najcięższy typ wagonu używany $w$ układzie, w którym ma mniejsza mase

f. dla normalnej, europejskiej eksploatacji, w której zespót trakcyjny $P-V$ pracuje $w$ mieszanym ruchu, $w$ otoczeniu zespotu trakcyjnego P-IV należy uwzględnić $w$ zderzeniu sztywna mase wynoszaca $55 t z$ pionowa płaszczyzna ( uproszczona przeszkoda reprezentujaca pojazd P-IV nie powinna mieć wptywu na zaabsorbowana energie $w$ tym wariancie zderzeń)

g. $\quad$ w przypadku normalnej europejskiej eksploatacji, jeśli zespót trakcyjny wystęuje jako eksploatowany w otoczeniu innych pojazdów, należy rozważyć kolizję z regionalnym zespotem trakcyinym

\section{Zestawienie wymagań dla III-giego wariantu zderzeń}

Tabela 7

\begin{tabular}{|c|c|c|c|c|}
\hline \multicolumn{5}{|c|}{ Prędkość zderzenia pojazdów pasażerskich $\mathbf{v}_{\mathbf{c}}^{\text {a, }}$} \\
\hline P-I & P-II & P-III & P-IV & P-V \\
\hline $110 \mathrm{~km} / \mathrm{h}^{\mathrm{b}, \mathrm{d}}$ & $110 \mathrm{~km} / \mathrm{h}^{\mathrm{b}, \mathrm{d}}$ & $110 \mathrm{~km} / \mathrm{h}^{\mathrm{b}, \mathrm{d}}$ & $40 \mathrm{~km} / \mathrm{h}^{\mathrm{d}}$ & $25 \mathrm{~km} / \mathrm{h}^{\mathrm{e}}$ \\
\hline
\end{tabular}

a. warunki zderzenia: zespól trakcyjny $w$ stanie nie zahamowanym na torze prostym

b. prędkość zderzenia dla pojazdów kategorii PI do PIII bazuje na prędkości eksploatacyjnej wynoszacej $160 \mathrm{~km} / \mathrm{h}$ na poziomych skrzyżowaniach. Jeśli prędkość eksploatacyjna pojazdu na poziomych skrzyżowaniach rożni się od $160 \mathrm{~km} / \mathrm{h}$, to wówczas prędkość zderzenia powinna być regulowana zgodnie z następujacym wzorem: $v_{c}=v_{o p}-50 \mathrm{~km} / \mathrm{h}$, gdzie $v_{o p}$ jest największa prędkościa eksploatacyjna na skrzyżowaniu. Prędkość v $v_{c}$ nie powinna być niższa niż $40 \mathrm{~km} / \mathrm{h}$ lub od prędkości eksploatacyjnej na skrzyżowaniu, na którym jest mniejsza.

c. $\quad$ sumaryczne opóźnienie hamowania $1.0 \mathrm{~m} / \mathrm{s}^{2}$. Prędkość zderzenia może być dodatkowo zmniejszona jeśli pojazdy maja opóźnienie hamowania $a_{d} \geq 1.0 \mathrm{~m} / \mathrm{s}^{2}$ zgodnie ze wzorem: $v_{\text {red }}=v_{c}\left(1-\left(11\left(a_{d}-1.0\right) / 36\right)\right)$

d. ciężkie przeszkody ( np. samochody ciężarowe) . Dla normalnej europejskiej eksploatacji sq one reprezentowane przez odkształcalne przeszkody, które sq zdefiniowane $w$ zataczniku prEN 15227:2005 [14]. Przeszkoda powinna być umieszczona symetrycznie prostopadle do kierunku ruchu zespotu trakcyjnego.

e. ciężkie przeszkody przeznaczone do zderzeń pod katem na skrzyżowaniach ( np. pojazdy do przewozu towarów lekkich). W normalnej, europejskiej eksploatacji one moga być reprezentowane przez sztywna mase o wartości $3 t$ z powierzchniq poprzeczna pokrywajaca pole kontaktu zderzenia z tramwajem. Płaszczyzna zderzenia znajduje sie pod katem $45^{\circ} w$ stosunku do osi wzdtużnej tramwaju $i$ jest umieszczona $w$ środku każdego narożnika czołowego. 
Zestawienie wymagań dla IV-go wariantu zderzeń

Tabela 8

\begin{tabular}{|l|c|c|c|c|c|}
\hline \multicolumn{5}{|c|}{ Pojazdy osobowe-kategorie P-I do P-IV } \\
\hline $\begin{array}{l}\text { Prędkość } \\
\text { eksploatacyjna }\end{array}$ & $\begin{array}{c}\geq 160 \\
\mathrm{~km} / \mathrm{h}\end{array}$ & $\begin{array}{c}140 \\
\mathrm{~km} / \mathrm{h}\end{array}$ & $\begin{array}{c}120 \\
\mathrm{~km} / \mathrm{h}\end{array}$ & $\begin{array}{c}100 \\
\mathrm{~km} / \mathrm{h}\end{array}$ & $\begin{array}{c}\leq 80 \\
\mathrm{~km} / \mathrm{h}\end{array}$ \\
\hline $\begin{array}{l}\text { Obciążenie } \\
\text { statyczne w } \\
\text { linii środkowej } \\
\text { b,c }\end{array}$ & $\begin{array}{r}300 \\
\mathrm{kN}\end{array}$ & $\begin{array}{c}240 \\
\mathrm{kN}\end{array}$ & $\begin{array}{c}180 \\
\mathrm{kN}\end{array}$ & $\begin{array}{c}120 \\
\mathrm{kN}\end{array}$ & $\begin{array}{c}60 \\
\mathrm{kN}\end{array}$ \\
\hline $\begin{array}{l}\text { Pochłonięta } \\
\text { energia w linii } \\
\text { środkowej }\end{array}$ & $36 \mathrm{~kJ}$ & $29 \mathrm{~kJ}$ & $22 \mathrm{~kJ}$ & $14 \mathrm{~kJ}$ & $7 \mathrm{~kJ}$ \\
\hline $\begin{array}{l}\text { Obciążenie } \\
\text { statyczne w } \\
\text { odległości } \\
\text { poprzecznej } \\
750 \text { mm od } \\
\text { C/L }\end{array}$ & 250 & 200 & 150 & 100 & $\begin{array}{l}50 \\
\mathrm{kN}\end{array}$ \\
\hline $\begin{array}{l}\text { Pochłonięta } \\
\text { energia w } \\
\text { odległości } \\
\text { poprzecznej } \\
750 \text { mm od } \\
\text { C/L L,e }\end{array}$ & $30 \mathrm{~kJ}$ & $24 \mathrm{~kJ}$ & $18 \mathrm{~kJ}$ & $12 \mathrm{~kJ}$ & $6 \mathrm{~kJ}$ \\
\hline
\end{tabular}

a. dla prędkości eksploatacyjnej różniqcej się od podanych wartości, wartości sit i energii moga być interpolowane

b. każde obciqżenie statyczne powinno być stosowane niezależnie $w$ kierunku wzdlużnym pojazdu. Siłe należy przyłożyć na polu o szerokości $0.5 \mathrm{~m}$ i wysokości $0.5 \mathrm{~m}$ od krawędzi powyżej dolnej powierzchni przeszkody. Linia działania sity powinna znajdować się na kierunku wzdlużnym $i$ przebiegać przez środek każdego załadowanego pola aż do maksymalnej wysokości wynoszqcej $500 \mathrm{~mm}$ powyżej główki szyny

c. obciażenia te nie powinny wywotywać znaczacego odksztatcenia trwałego na przeszkodzie a ich przyłożenie do ostoi odpowiada kazdemu tadunkowi statycznemu

d. jeśli przeszkoda jest przeciażona, to wówczas może wystapić odkształcenie plastyczne $w$ taki sposób, że spowoduje oderwanie lub zagrożenie

e. $\quad w$ trakcie plastycznej deformacji na przeszkodzie wymaganej przez prEN 15227:2005[14] powinny być pochtonięte przynajmniej wartości energii podane $w$ powyższej tabeli.

\subsection{Bezpieczeństwo osobowych pojazdów szyno- wych zgodnie z przepisami amerykańskimi}

Nieco inną filozofię bezpieczeństwa przed zderzeniem dla konstrukcji pojazdów szynowych prezentuje Amerykańskie Ministerstwo Transportu, które wydało bardzo surowe przepisy dotyczące zespołów trakcyjnych przystosowanych do wysokich prędkości przekraczających $200 \mathrm{~km} / \mathrm{h}[7,8]$. W strefie początkowej zespołu trakcyjnego oraz na jego końcu nie mogą znajdować się miejsca dla podróżnych; strefa kabiny dla maszynisty może ulec deformacji pod wpływem sił o wartości $10 \mathrm{MN}$, natomiast przedziały dla podróżnych (lub pomieszczenia dla podróżnych) przy siłach wynoszących 3,6 MN. Zdolność do przejmowania energii przez człon napędowy oraz przez pierwszy wagon musi wynosić przynajmniej 13MJ ( za wyjątkiem strefy zajętej przez pasażerów). Strefy kontrolowanego zgniotu nadwozia (pudła pojazdu) mogą wykazać odkształcenia przy siłach o wartościach mniejszych niż 3,6 MN.
Maksymalne opóźnienie w przedziałach dla podróżnych jest ograniczone do wartości $8 \mathrm{~g}\left(78,5 \mathrm{~m} / \mathrm{s}^{2}\right)$. W przypadku, kiedy poziom sił jest ograniczony do $2,5 \div 3$ MN, wówczas konieczne jest ograniczenie odkształcenia pojazdu do około $5 \mathrm{~m}$. Zróżnicowanie wymagań dla zespołów trakcyjnych użytkowanych na terenie różnych zarządów europejskich oraz znajdujących się na różnych kontynentach wynika ze specyfiki poszczególnych tras kolejowych. Nowoczesny zespół trakcyjny przystosowany do wysokich prędkości „Schinkansen” eksploatowany w Japonii, można ocenić jako zamknięty system transportu osobowego, wyposażony w niezawodny, wydajny system aktywnego bezpieczeństwa przed zderzeniami. W przypadku kolei europejskich występuje eksploatacja mieszana, gdzie na trasach kolejowych odbywa się jednoczesny transport ładunków oraz transport osobowy. Poza tym część tras kolejowych nie jest jeszcze zmodernizowana i przystosowana do wysokich prędkości. W przypadku państw północnoamerykańskich trasy kolejowe są użytkowane zasadniczo do transportu ładunków, na których są realizowane ciężkie przewozy towarowe, natomiast transport osobowy ma charakter marginalny.

\section{Kryteria eksploatacyjne oceny bezpieczeństwa pojazdów szynowych przed skutkami przejęcia energii zderzenia}

\subsection{Przyspieszenie w kierunku pionowym}

Jak wynika z aktualnych prac studialnych, przyspieszenie w kierunku pionowym może być wykorzystywane jako istotny parametr $\mathrm{w}$ zapewnieniu bezpieczeństwa aktywnego pojazdu szynowego ( między innymi unikanie zjawiska wykolejenia )[2]. Parametr ten był przedmiotem rozlicznych prac analitycznych po wykolejeniach, które miały miejsce na sieci kolei szwajcarskich SBB w 1994 roku, gdzie doszło do poważnych strat materialnych i skażenia środowiska naturalnego oraz konieczności ewakuowania mieszkańców z terenów objętych katastrofami kolejowymi (wykolejeniu uległy wagony cysterny przewożące ładunki niebezpieczne). Wielkość tego parametru dla różnych stanów eksploatacyjnych przedstawiono w tabeli 9. Na podstawie danych zawartych w tabeli 9 wyciągnięto wniosek, że mierząc przyspieszenie pionowe za pomoca detektora zamocowanego na czołownicy wagonu cysterny można zapobiec wykolejeniu przez podanie sygnału „otwierającego” zawór główny, co powoduje hamowanie nagłe pociagu. Jako ostateczną wartość przyspieszenia pionowego, powyżej którego może nastapić wykolejenie ustalono $\mathbf{7 , 5} \mathbf{5}^{ \pm 0.5} \mathrm{~g}\left(\mathbf{7 3}, \mathbf{6}^{\mathbf{4 . 9}}\right.$ $\mathbf{m} / \mathbf{s}^{2}$ ). Detektor wykolejenia typu EDT 100 zabudowany na czołownicy wagonu ma za zadanie możliwie natychmiastowe wykrycie wykolejonego zestawu kołowego pojazdu szynowego i poprzez wprowadzenie hamowania nagłego zabezpieczenie pojazdu przed 
skutkami wypadku. Detektor składa się z trzech zasadniczych części:

- zaworu bezpieczeństwa typu NV3 homologowanego w UIC

- zaworu sprężynowego

- urządzenia wskazującego.

\section{Zestawienie przyspieszeń pionowych w różnych stanach eksploatacyjnych}

Tabela 9

\begin{tabular}{|c|c|c|c|}
\hline \multirow[b]{2}{*}{ Typ eksploatacji } & \multicolumn{3}{|c|}{$\begin{array}{l}\text { zakres maksymalnych przyspieszeń } \\
\text { pionowych }\end{array}$} \\
\hline & $\begin{array}{l}\text { Na czo- } \\
\text { łownicy } \\
\text { ostoi }\end{array}$ & $\begin{array}{c}\text { Na pokrywie } \\
\text { maźnicy }\end{array}$ & $\begin{array}{l}\text { W środku } \\
\text { wagonu }\end{array}$ \\
\hline $\begin{array}{l}\text { Normalna jazda } \\
\text { eksploatacyjna : } \\
\text {-prędkość } 40 \text { do } 100 \mathrm{~km} / \mathrm{h} \text {, } \\
\text {-załadunek: próżny/ladowny }\end{array}$ & 1.6 do $1.8 \mathrm{~g}$ & 8.8 do $10.3 \mathrm{~g}$ & około $5.5 \mathrm{~g}$ \\
\hline $\begin{array}{l}\text { Plaskie miejsca na kole- } \\
\text { (obliczenia symulacyjne): } \\
\text {-prędkość } 10 \text { do } 80 \mathrm{~km} / \mathrm{h} \\
\text {-wysokość płaskich miejsc } \\
\text { 4/6/8/12 mm na kole }\end{array}$ & 0.9 do $4.1 \mathrm{~g}$ & 1.1. do $22 \mathrm{~g}$ & 1.9 do $25 \mathrm{~g}$ \\
\hline $\begin{array}{l}\text { Styki szyn ( obliczenia sy- } \\
\text { mulacyjne): } \\
\text {-prędkość } 10 \text { do } 80 \mathrm{~km} / \mathrm{h} \text {, } \\
\text {-stan załadowania: } \\
\text { próżny/ladowny } \\
\text {-wysokość nierówności pio } \\
\text { nowych } 10 \text { do } 15 \mathrm{~mm} \text { na } \\
\text { torze }\end{array}$ & 1.9 do $4.6 \mathrm{~g}$ & 5.6 do $20 \mathrm{~g}$ & 5.9 do $14.9 \mathrm{~g}$ \\
\hline Stan wykolejenia & 11.1 do $52 \mathrm{~g}$ & 42 do $52 \mathrm{~g}$ & 14,1 do $68,6 \mathrm{~g}$ \\
\hline
\end{tabular}

Uwaga: wymienione zakresy wartości przyspieszeń obowiazuja dla stanu próżnego oraz ładownego
Transportation i Siemens Transportation Systems) jak również europejskich centrów badawczych (AEA Technology Derby, CIC Cranfield, CNTK Warszawa, IST Lissabon, Technische Universität Dresden i UVHC Valenciennes). Zestawienie sił deformujących $\mathrm{z}$ odpowiadającym im przemieszczeniem deformującym dla poszczególnych wariantów zespołów trakcyjnych przedstawiono w tabeli 10.

Zespoły trakcyjne podzielono na cztery następujące grupy:

- zespoły trakcyjne typu A: masa własna 340 t ( 8 członów włącznie $z$ jednym członem napędowym)

- zespoły trakcyjne typu B: masa własna 412 t ( 8 członów włącznie $\mathrm{z}$ dwoma wagonami sterowniczymi)

- zespoły trakcyjne typu C: masa własna 129 t ( 3 człony włącznie $\mathrm{z}$ dwoma wagonami sterowniczymi)specjalnie wybrany do realizacji projektu badawczego SAFETRAIN

- zespoły trakcyjne typu D: masa własna 50 t ( człon napędowy).

\subsection{Sily deformujące ( niem. Stauchkräfte)}

Ważnym kryterium, które decyduje o bezpieczeństwie pojazdów szynowych podczas zderzeń jest zdolność do przejmowania przez konstrukcje sił deformujących. Sily te zostały określone dla zespołów trakcyjnych w projekcie SAFETRAIN, który był realizowany przez konsorcjum składające się $\mathrm{z}$ przedstawicieli kolei europejskich (DB AG, SNCF), przemysłu taboru europejskiego ( Alstom, Bombardier

Zestawienie sil deformujących dla różnych typów zespołów trakcyjnych oraz odpowiadające im przemieszczenia deformacyjne.

Tabela 10

\begin{tabular}{|c|c|c|c|c|c|c|}
\hline & \multicolumn{6}{|c|}{ Siły ściskajace w [ kN] } \\
\cline { 2 - 7 } & \multicolumn{2}{|c|}{$\begin{array}{c}\text { Pomiędzy członami skrajnymi ze- } \\
\text { społów trakcyinych }\end{array}$} & \multicolumn{2}{c|}{$\begin{array}{c}\text { Pomiędzy elementami środko- } \\
\text { wymi }\end{array}$} \\
\hline Typ zespołu & Sprzęg & $\begin{array}{c}\text { Elementy } \\
\text { zderzne }\end{array}$ & $\begin{array}{c}\text { Konstrukcja } \\
\text { pudła } \\
\text { wagonu }\end{array}$ & Sprzęg & $\begin{array}{c}\text { Elementy } \\
\text { zderzne }\end{array}$ & $\begin{array}{c}\text { Konstrukcja } \\
\text { pudła } \\
\text { wagonu }\end{array}$ \\
\hline A & 950 & 1950 & 3370 & 1065 & 2000 & 2750 \\
\hline B & 950 & 1895 & 3315 & 1055 & 2000 & 3000 \\
\hline C & 920 & 1895 & 3185 & 1090 & 2040 & 3000 \\
\hline D & 600 & 1800 & 2500 & - & - & - \\
\hline $\begin{array}{l}\text { Przemieszczenie } \\
\text { deformujące w } \\
\text { [mm] }\end{array}$ & 100 & 800 & 1000 & 200 & 200 & 500 \\
\hline
\end{tabular}


- $\quad$ przebieg odkształcenia w tej strefie kontrolowanego zgniotu nadwozia (niem.,, Knautschzone") musi mieć charakter progresywny

- $\quad$ strefa gwarantująca przeżycie musi posiadać minimalną długość wynoszącą $0,75 \mathrm{~m}$ i musi być zagwarantowana droga ucieczki dla maszynisty

- $\quad$ zapobieżenie rozerwaniu się części należących do konstrukcji pojazdu względnie jego wyposażenia; zapobieżenie wykolejeniu pojazdu

- $\quad$ przyjąć wartości maksymalne sił ściskających trwające mniej niż $5 \mathrm{~ms}$ podczas procesu zgniotu

- $\quad$ zachowanie integralności stref przebywania dla pasażerów podczas całego procesu zgniatania, również w przypadku występowania sił szczytowych; można zaakceptować

- $\quad$ konieczne jest zastosowanie urządzeń zapobiegających unoszeniu się pojazdu podczas zderzenia, które reagują przy obciążeniu pionowym wynoszącym $150 \mathrm{kN}$ i które są przygotowane do działania przy różnicy wysokości wynoszącej $100 \mathrm{~mm}$ i ponadto zastosowanie sprzęgieł, które umożliwiają wcześniejsze zadziałanie oraz kompatybilność z innymi pojazdami np. ze zderzakami

- $\quad$ urządzenia zgarniające ( zgarniacze) nie mogą utrudniać procesu zgniotu; powinny być one rozmieszczone możliwie daleko przed kabiną maszynisty

- $\quad$ przepisy Międzynarodowego Związku Kolejowego UIC dla statycznych obciążeń badawczych nie mogą być sprzeczne z wymaganiami bezpieczeństwa przed zderzeniami.

\subsection{Kryterium opóźnienia w kierunku wzdłużnym ( ang. deceleration limit)}

Wartość opóźnienia biegu pojazdu jest uwarunkowana efektywną wielkością siły oporu. Wartość efektywnej siły oporu jest różnicą pomiędzy siłami działającymi na przeciwległych końcach pojazdu w przedziale czasu. Poziomy sił znacznie wyższe niż przeciętne są dopuszczalne pod warunkiem, że nie działają w sposób ciagły. Główne opóźnienie w strefie przeżycia ( ang. survival space) pojazdu powinno być ograniczone $\mathrm{w}$ praktyce do $5 \mathrm{~g}\left(\mathbf{4 9 . 0 5} \mathrm{m} / \mathrm{s}^{2}\right)$ i nie może przekroczyć wartości $7.5 \mathrm{~g}\left(\mathbf{7 3 . 5 7} \mathrm{m} / \mathrm{s}^{2}\right)$. Wartość ta może być użyta do przyjęcia wyższych poziomów opóźnień w zamkniętej przestrzeni kabiny maszynisty lub motorniczego w momencie zderzenia. Metoda określania głównego opóźnienia dla każdego rozważanego pojazdu w składzie pociągu polega na jego ustaleniu w określonym przedziale czasowym zdefiniowanym od chwili, kiedy efektywna siła kontaktowa na pojeździe jest większa od zera, do czasu kiedy po kolejnych obniżeniach osiagnnie znów wartość zerową. Wytrzymałość urządzeń wyposażenia pojazdu powinna być rozpatrywana $\mathrm{w}$ aspekcie poziomu przyjętego kryterium opóźnienia.

\subsection{Energia kinetyczna wybranego wagonu}

Przy rozpatrywaniu zderzeń oraz środków zapobiegawczych lub łagodzących skutki zderzeń, decydującym kryterium jest wielkość energii kinetycznej poruszającego się pojazdu. Korzystając ze wzoru (1) obliczono energię kinetyczną dla wagonu-cysterny 458R, przy różnych prędkościach, w stanie próżnym oraz maksymalnie załadowanym (masa brutto $90000 \mathrm{~kg}$ ), a wyniki zamieszczono w tabeli 11 .

Zestawienie wyników obliczeń energii kinetycznej dla wagonu cysterny typu $458 \mathrm{R}$

Tabela 11

\begin{tabular}{|l|c|c|c|c|c|c|c|c|c|c|c|c|}
\hline & \multicolumn{4}{|c|}{ PREDKOSĆ WAGONU } & {$[\mathrm{km} / \mathrm{h}]$} & \multicolumn{7}{c|}{ ENERGIA KINETYCZNA EK [kJ] } \\
\hline $\begin{array}{l}\text { Stan } \\
\text { wagonu }\end{array}$ & $\mathrm{v}=10$ & $\mathrm{v}=15$ & $\mathrm{v}=20$ & $\mathrm{v}=30$ & $\mathrm{v}=40$ & $\mathrm{v}=50$ & $\mathrm{v}=60$ & $\mathrm{v}=70$ & $\mathrm{v}=80$ & $\mathrm{v}=90$ & $\mathrm{v}=100 *$ \\
\hline Próżny & 99 & 223 & 396 & 892 & 1586 & 2478 & 3569 & 4858 & 6345 & 8031 & $9915^{3)}$ \\
\hline $\begin{array}{l}\text { Ladowny }^{1)} \\
80000 \mathrm{~kg}\end{array}$ & 308 & 694 & 1234 & 2777 & 4938 & 7716 & 11110 & 15123 & 19750 & 25000 & 30860 \\
\hline $\begin{array}{l}\text { Ladowny }^{20} \\
90000 \mathrm{~kg}\end{array}$ & 347 & 781 & 1388 & 3125 & 5555 & 8680 & 12500 & 17013 & 22220 & 28125 & 34722 \\
\hline
\end{tabular}

*) MAKSYMALNA DOPUSZCZALNA PRE¿DKOŚĆ EKSPLOATACYJNA WAGONU CYSTERNY W STANIE ŁADOWNYM, 1) ODPOWIADAJACCY NACISKOWI ZESTAWU KOŁOWEGO NA SZYNY $20 t$

2) ODPOWIADAJACCY NACISKOWI ZESTAWU KOLOWEGO NA SZYNY $22.5 t$

3) DLA WAGONU PRÓŻNEGO DOPUSZCZALNA PREKOŚĆ EKSPLOATACYJNA WYNOSI $120 \mathrm{~km} / \mathrm{h}$ (KARTA UIC 432 [9]) I ENERGIA KINETYCZNA WYNOSI ODPOWIEDNIO $14270 \mathrm{~kJ}$ 
Zestawienie wyników obliczeń wskaźnika energii kinetycznej dla wagonu cysterny typu $458 \mathrm{R}$ niezależnego od stanu załadowania dla różnych prędkości eksploatacyjnych

Tabela 12

\begin{tabular}{|c|c|c|c|c|c|c|c|c|c|c|c|}
\hline & \multicolumn{11}{|c|}{ PREDKOSĆ WAGONU TOWAROWEGO w [km/h] } \\
\hline & $\mathrm{v}=10$ & $\mathrm{~V}=15$ & $\mathrm{v}=20$ & $\mathrm{~V}=30$ & $\mathrm{~V}=40$ & $\mathrm{v}=50$ & $\mathrm{v}=60$ & $\mathrm{v}=70$ & $\mathrm{v}=80$ & $\mathrm{v}=90$ & $\mathrm{~V}=100 *$ \\
\hline $\mathrm{E}_{\mathrm{k}}[\mathrm{J} / \mathrm{kg}]$ & 3.85 & 8.67 & 15.40 & 34,70 & 61,71 & 96,42 & 138,87 & 189,02 & 246,88 & 312,49 & $385,79^{1)}$ \\
\hline
\end{tabular}

*) MAKSYMALNA DOPUSZCZALNA PREDKOŚĆ EKSPLOATACYJNA WAGONU CYSTERNY W STANIE ŁADOWNYM

1) DLA WAGONU PRÓŻNEGO DOPUSZCZALNA PRĘKOŚĆC EKSPLOATACYJNA WYNOSI $120 \mathrm{~km} / \mathrm{h}$ (KARTA UIC 432 [9]) I ENERGIA KINETYCZNA WYNOSI ODPOWIEDNIO $14270 \mathrm{~kJ}$, NATOMIAST WSKAŹNIK ENERGII KINETYCZNEJ WYNOSI ODPOWIEDNIO 555,53 J/kg MASY WEASNEJ

Tabela 12 zawiera zbiór danych do poszukiwania tzw. najgorszego przypadku (ang. ,worst case”). Na ich postawie można przedstawić wskaźnik energetyczny pojazdu wyrażający ilość MJ (lub w kJ) przypadających na kg masy własnej poruszającego się wagonu. Wskaźnik ten będzie przydatny do ewentualnej analizy przy rozważaniu konstrukcji mogącej przejąć energię przy zderzeniu.

\section{Wnioski}

Analizując stan aktualnych przepisów międzynarodowych dotyczących bezpieczeństwa pasywnego pojazdów szynowych zabezpieczających je przed skutkami zderzeń można stwierdzić, że opracowane kryteria $\mathrm{w}$ tym zakresie odpowiadają specyfice każdego typu pojazdu szynowego. Stosowanie uniwersalnego rozwiązania zwiększającego bezpieczeństwo pasywne wszystkich pojazdów w równym zakresie jest niemożliwe, ze względu na ich różne parametry i cechy. W związku z tym bezpieczeństwo pojazdu należy traktować indywidualnie. Można przypuszczać, że w najbliższej już perspektywie kryteria te w miarę rozwoju pojazdów szynowych będą ulegały stopniowemu zaostrzaniu, co będzie wynikało między innymi z wzrastającej konkurencji pomiędzy rywalizującymi ze sobą różnymi przedsiębiorstwami transportowymi, gdyż bezpieczeństwo jazdy w szeroko rozumianym zakresie jest podstawowym parametrem oceny poszczególnych środków transportowych. Kryteria bezpieczeństwa pasywnego będą musiały spełniać nie tylko nowobudowane pojazdy szynowe, ale również już eksploatowane, które w ramach modernizacji będą musiały być wyposażone w nowoczesne środki konstrukcyjne, redukujące skutki zderzeń (np. wyposażenie w elementy zderzno-pochłaniające oprócz tradycyjnych zderzaków). W przypadku wagonów towarowych cystern przewożących materiały niebezpieczne i podlegających przepisom RID [16] należy wyjść z założenia, że zwiększenie bezpieczeństwa pasywnego tych pojazdów, oprócz poprawienia niezawodności transportu ładunków, sprzyja niewątpliwie ochronie środowiska.

\section{Literatura}

[1] Hondius H.: Rotterdam bestellt RandstadRailzüge. Stadtverkehr 7/8 2005.

[2] Hubacher W., Scheiber P.: Entgleisungsdetektion beim Rollmaterial der SBB. Schienen der Welt. 11/2000.

[3] Wolter W.: Kollisionssicherheit- ein Qualitätsmerkmal der passiven Sicherheit der Schienenfahrzeuge. ZEV+DET. Glassers Annalen 9/10 2001.

[4] Wolter W.: Kollisionssicherheit von Stadt-und Strassenbahnen. Entwicklung der passiven Sicherheit leichter Nahverkehrsfahrzeuge. EI- Eisenbahningenieur 2.2002.

[5] Wolter W.: Kollisionssichere Schienenfahrzeuge. Empfehlungen für Hersteller und Betreiber. ZEVRail Glassers Annalen Nr. 128 2004. Tagungsband SFT Graz 2004.

[6] Zehnder J.: Über die Crashsicherheit von Aluminium-Wagenkasten. ZEV+DET Glassers Annalen Nr.125 9/102001.

[7] Dokument techniczny. American Public Transportation Association: APTA SS-C\&S034-99. Standard for the Design and Construction of Passenger Railroad Rolling Stock.

[8] Dokument techniczny. Department of Transformation. Federal Railroad Administration. 49CFR Part 216 et al. Passenger Equipment Safety Standard. Finale Rule.

[9] Karta UIC 432: Wagony towarowe. Prędkości jazdy. Warunki techniczne, które należy spetnić. 10-te wydanie z 10.2005

[10] Karta UIC 526-1: Wagony towarowe. Zderzaki o skoku $105 \mathrm{~mm}$. 2-gie wydanie z 1.07.1998.

[11] Karta UIC 529:Wagony towarowe. Amortyzatory hydrodynamiczne o duży skoku. Warunki techniczne. 1-sze wydanie z 1.01.1978.

[12] Karta UIC 566: Obciażenia pudet wagonów pasażerskich i ich części dobudowanych. 3-cie wydanie z 1.01.1990 
[13] Karta UIC 571-2: Wagony towarowe zunifikowane. Wagony towarowe wózkowe ogólnego przeznaczenia. Charakterystyki. 6-te wydanie z 02.2001 .

[14] pr EN 15 227:Kolejnictwo. Wymagania odporności na zderzenia nadwozi pojazdów szynowych. (Railway applications. Crashworthiness requirements for railway vehicle bodies). kwiecień 2005.

[15] Raport ERRI B 205 Rp.1: Analiza statystyczna bazy danych dotyczacej wypadków. Sponsor: Komisja Transportu Osobowego. (Statistical Analysis Accidents Database. Sponsoring body: UIC Passenger Commision).

[16] RID Regulamin dla międzynarodowego przewozu kolejami towarów niebezpiecznych. Aneks 1 do załacznika B konwencji (Umowy) o międzynarodowym przewozie towarów kolejami (CIM). Grupa PKP-Przewozy Towarowe CARGO. Wyd. 01.07.2001.
[17] Schlussbericht ERRI B12/Rp.17 (8-me wydanie): Program prób wagonów towarowych $z$ podwoziem i strukturq wagonu ze stali (które nadaja się do zabudowy sprzęgu pracujacego na rozciaganie i na ściskanie) i których wózki maja rame stalowa.(Versuchsprogramm für Güterwagen mit Untergestell und Wagenkasten aus Stahl (die für den Einbau der Automatischen Zug-Druck Kupplung geeignet sind) und deren Drehgestelle mit stählernem Drehgestellrahmen). Utrecht, kwiecień 1997.

[18] UIC-CTR Dokument: SAFETRAIN. Bezpieczeństwo przed zderzeniami pociagów dla Europy. Wnioski końcowe i zalecenia. ( SAFETRAIN. Zug-Kollisionssicherheit für Europa. Schlussfolgerungen und Empfehlungen). Paryż, lipiec 2001. 